\title{
National science furore
}

\section{Grants awarded through peer review should not then be subject to political 'accountability'.}

The fiscal cliff was avoided but the sequester has cut deep. Finally, in late March, the US Congress settled on a continuing resolution for government spending in the current fiscal year, and although the bill goes some way to alleviate the worst of the sequester, the overall $\$ 85$ billion cut in 'discretionary spending' - which takes in most of the US science agencies - is still firmly in place. The situation is unlikely to improve in the next financial year, despite there being a modest increase in spending on research and development included in the President's budget request for 2014. In a speech ${ }^{1}$ marking the 150th anniversary of the founding of the National Academy of Sciences (NAS), President Obama acknowledged the damage caused. "We could lose a year, two years of scientific research as a practical matter because of misguided priorities", he warned.

Those 'misguided priorities' have become more apparent - and are not only about the amount of cash given over to research. When the 2013 spending bill passed, it included an amendment made by Republican Senator Tom Coburn that excluded the granting of funds by the National Science Foundation (NSF) to any research in political science that was not tied to economic development or national security. "We have no money", President Obama joked with the NAS gathering, and in the midst of such economic woes hard decisions must indeed be made about priorities. But Coburn's stipulation of how funds may or may not be distributed within an agency was disconcerting.

And it did herald worse to come. In April, Republican Representative Lamar Smith circulated a draft bill, entitled the 'High Quality Research Act', which would require the NSF to demonstrate to Congress that its grants "advance the national health, prosperity or welfare" or secure national defence. Smith is Chairman of the House Committee on Science, Space and Technology. A day earlier, Director of the White House Office of Science and Technology Policy John Holdren and acting Director of the NSF Cora Marrett had appeared before that committee and been questioned about the NSF's process of peer review and its criteria for funding decisions. "I think it's a dangerous thing for Congress, or anybody else, to be trying to specify in detail what types of fundamental research NSF should be funding", Holdren said ${ }^{2}$. Following the science committee hearing, Smith wrote

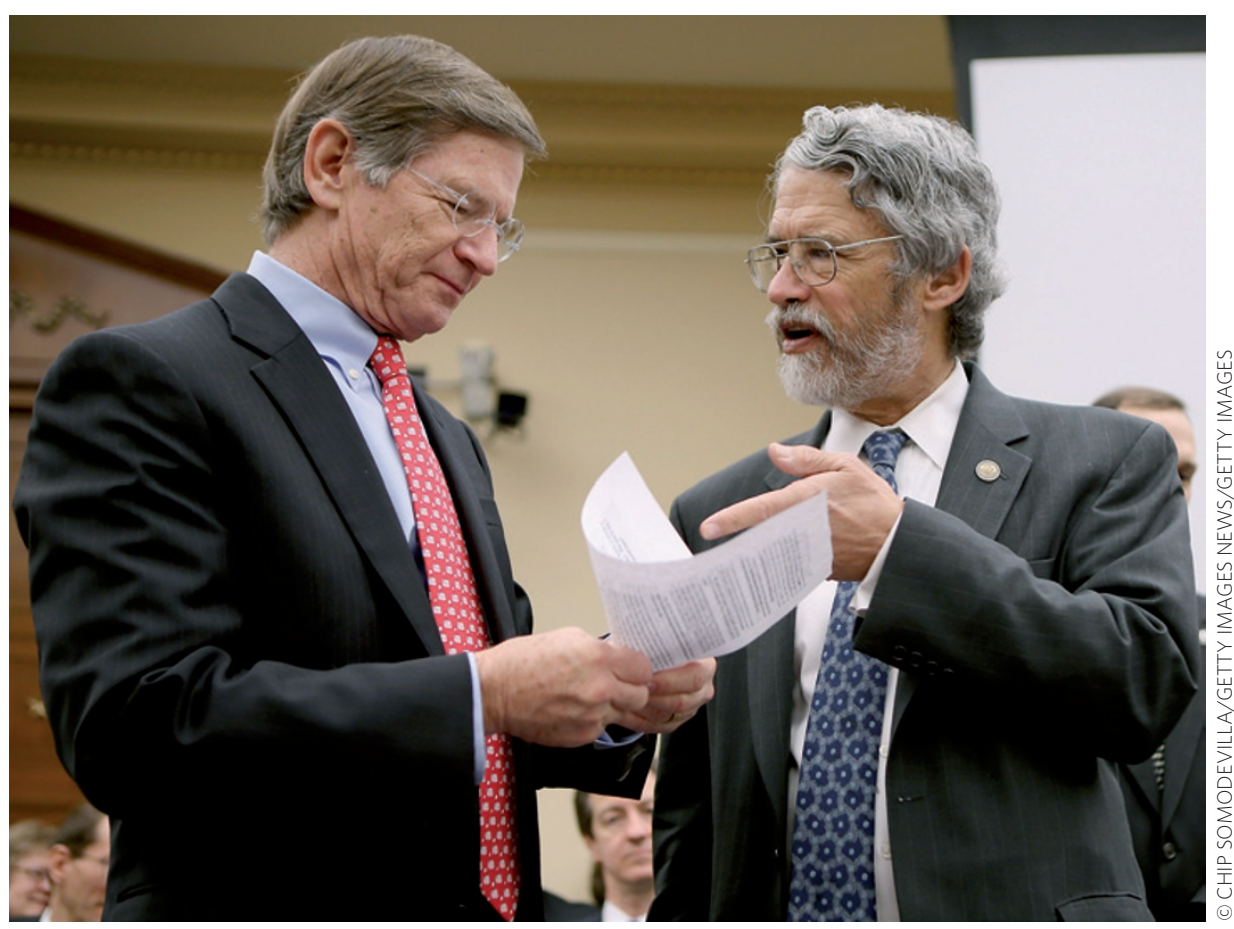

Much to discuss: Representative Lamar Smith and presidential science advisor John Holdren.

to Marrett to query the award of five specific grants in the social sciences, and request "access to the scientific/technical reviews".

Unsurprisingly, US scientists are up in arms; petitions have been opened online, from "Stop the NSF legislation being put forth by Lamar Smith" (at change.org) to "Don't let Lamar Smith take over the sciences!" (watchdog.net). Smith has protested that his bill "maintains the current peer review process and improves on it by adding a layer of accountability". But Democrat Representative Eddie Bernice Johnson, who also serves on the House Science Committee, has countered ${ }^{3}$ that it sends "a chilling message to the entire scientific community that peer review may always be trumped by political review".

In an anonymous interview with Science magazine ${ }^{4,5}$, a committee aide explained that "Congress is saying that we think an additional step is needed to solve the problem of why so many questionable grants are being awarded." "Adding Congress as reviewers is a mistake", maintains Holdren ${ }^{3}$.

Marrett has since responded to Smith's request for information on the five 'questionable' NSF grants - refusing to release details of their peer review. Instead she has offered to brief the House Science Committee generally on how the NSF arrives at decisions on the roughly 40,000 applications it receives annually (about 1 in 5 are successful).

Scientists are well aware of the benefits and shortcomings - of peer review, and Holdren has signalled a willingness to look at the process "to make sure that it is everything it can be". But it would be no kind of advance to direct funds for fundamental research according to national interests as defined by politicians. When money is tight, when so much more must be done with so much less, it is the ingenuity of scientists and their integrity in peer review that offer the best chance of scientific success.

\section{References}

1. Southall, A. The New York Times (17 May 2013); http://go.nature.com/6lgQTb

2. Little, M. Los Angeles Times (1 May 2013); http://go.nature.com/gI7mZt

3. Walsh, D. The New Yorker (9 May 2013); http://go.nature.com/c1YPaw

4. Mervis, J. Science 340, 670 (2013).

5. Mervis, J. ScienceInsider (9 May 2013); http://go.nature.com/Y7OToY 